Canadian Journal of Plant Science Revue canadienne de phytotechnie

\title{
Tankmixture of glyphosate with 2,4-D accentuates 2,4-D injury in glyphosate-resistant corn
}

\begin{tabular}{|r|l|}
\hline Journal: & Canadian Journal of Plant Science \\
\hline Manuscript ID & CJPS-2017-0241.R2 \\
\hline Manuscript Type: & Article \\
\hline Date Submitted by the Author: & $17-$ Dec-2017 \\
\hline Complete List of Authors: & $\begin{array}{l}\text { Soltani, Nader; University of Guelph, Ridgetown Campus } \\
\text { Shropshire, Christy; University of Guelph - Ridgetown Campus, } \\
\text { Sikkema, Peter; University of Guelph, Dept. Plant Agriculture }\end{array}$ \\
\hline Keywords: & $\begin{array}{l}\text { Crop injury, height, stand, goosenecking, brace root malformation, cob } \\
\text { deformity, corn yield, Zea mays. }\end{array}$ \\
\hline
\end{tabular}

\section{SCHOLARONE ${ }^{m}$ \\ Manuscripts}


Tankmixture of glyphosate with 2,4-D accentuates 2,4-D injury in glyphosate-resistant corn

Nader Soltani, Christy Shropshire and Peter H. Sikkema

\begin{abstract}
Six field trials were conducted at Ridgetown, Ontario over a two-year period (2015 and 2016) to determine the tolerance of two corn hybrids to 2,4-D (560 and $\left.1120 \mathrm{~g}^{2} \mathrm{~h} \mathrm{ha}^{-1}\right)$ and glyphosate (1800 $\mathrm{g}$ ae ha $\left.{ }^{-1}\right)$ applied alone or in combination at V1, V3 or V5. In DeKalb DKC5261 corn, 2,4-D caused as much as 24, 16, 11 and 11\% visible injury at 1 WAT, 2 WAT, 4 WA-C and 8 WA-C, respectively. Plant stand was not affected, but plant height decreased $5 \mathrm{~cm}$ at $560 \mathrm{~g}$ ai ha ${ }^{-1}$ and $7 \%$ at $1120 \mathrm{~g}_{\text {ai ha }}{ }^{-1}$. As the application timing was delayed from V1 to V5, there was a trend to increase injury at both 2,4-D rates. Corn yield decreased $8 \%$ with 2,4-D applied at 560 $\mathrm{g}$ ai ha ${ }^{-1}$ and $12 \%$ at $1120 \mathrm{~g} \mathrm{ai} \mathrm{ha}^{-1}$. In Pioneer P0094AM corn, 2,4-D caused as much as 16, 9, 7 and 7\% visible injury at 1 WAT, 2 WAT, 4 WA-C and 89 WA-C, respectively. Plant height was not affected, but goosenecking and brace root malformation were increased as the rate of 2,4-D was increased. There was generally no difference between glyphosate rates (1800 vs $0 \mathrm{~g} \mathrm{ae} \mathrm{ha}^{-1}$ ) at V1 corn stage but visible injury, goosenecking and brace root malformation at other application timings was as much as 15, 3 and 19\% greater when 2,4-D was applied in a
\end{abstract}

Received 4 August 2017, accepted XX XX 2017.

N. Soltani, C. Shropshire, and P.H. Sikkema. University of Guelph Ridgetown Campus, Ridgetown, ON NOP 2C0, Canada.

Corresponding author: Nader Soltani (e-mail: soltanin@uoguelph.ca).

Abbreviations: POST, postemergence; V1, 1 corn leaf collar visible; V3, 3 corn leaf collars visible; V5, 5 corn leaf collars visible; WAT, weeks after each postemergence herbicide application; WA-C, weeks after last postemergence herbicide application. 
tankmixture with glyphosate, respectively. Yield was reduced 12\% when 2,4-D (1120 $\left.\mathrm{g}_{\text {ai ha }}{ }^{-1}\right)$ was applied with glyphosate in the tankmixture.

Key words: Crop injury, goosenecking, brace root malformation, cob deformity, Zea mays.

\section{Introduction}

As of 2016, glyphosate-resistant (GR) Canada fleabane, giant ragweed, waterhemp and common ragweed have been confirmed in 30,6,3, and 1 counties in Ontario, respectively (Follings et al. 2013; Van Wely et al. 2015; Budd et al. 2017; Schryver et al 2017). With the recent evolution of GR weeds, there has been a increased interest in the use of 2,4-D applied late postemergence for the control of GR weeds such as Canada fleabane (Johnson et al. 2012).

Studies by Kruger et al. (2010) have shown that 2,4-D amine or ester (560 $\left.\mathrm{g}^{\mathrm{ae} \mathrm{ha}} \mathrm{ha}^{-1}\right)$ controlled GR Canada fleabane greater than 90\%. Byker et al. (2013) reported that 2,4-D ester plus glyphosate $\left(500+900 \mathrm{~g}\right.$ ae ha $\left.^{-1}\right)$ applied preplant to soybean controlled GR Canada fleabane as much as 92\%. Glyphosate-resistant weeds such as Canada fleabane have an extended germination and emergence pattern (Keeling et al. 1995). Growers in Ontario sometimes add 2,4-D amine to their last in-crop application of glyphosate to control GR Canada fleabane in corn. This combination has resulted in severe corn injury in some Ontario fields.

2,4-dichlorophenoxyacetic acid is a widely used herbicide that was first synthesized in 1941 and commercialized in the United States in 1944 (Munro et al. 1992; Peterson et al. 2016). It is a phenoxy herbicide that is readily absorbed through foliage and roots (Shaner 2014; Peterson et al. 2016). It is mainly translocated through phloem although it can also move with water in the 
xylem (Peterson et al. 2016). 2,4-D has greater activity on broadleaf weeds compared to grasses mainly due to differences in the interception, translocation and metabolism and sensitivity of the active sites (Peterson et al. 2016; OMAFRA 2017). In susceptible plants, 2,4-D causes uncontrolled cell division resulting in epinasty and abnormal leaf development which is followed by yellowing of the growing points, wilting, necrosis and plant death within 3-5 weeks (Peterson et al. 2016; OMAFRA 2017). After more than 70 years of use, there are 34 weed species that are resistant to the Group 4 herbicides (http://weedscience.org/), but, generally, they are not widespread (Johnson et al. 2012).

Studies conducted in late 1940 s to early 1950 s with both field and sweet corn have shown differential sensitivity of corn to 2,4-D (Ellis and Bullard 1948; Rossman and Sprague 1949; Rossman and Staniforth 1949; Rodgers 1952). These early studies concluded that corn hybrids respond differently to 2,4-D application; and the response is dependent on application rate and timing (Guzman and Wolf 1952). Corn hybrids have evolved tremendously in the last half century. Genetically engineered glyphosate/glufosinate-resistant corn hybrids were introduced in 1996 and have revolutionized corn production systems (Johnson et al. 2012).

Glyphosate/glufosinate-resistant corn have been widely adopted by farmers across North America because of improved weed control, reduced crop injury, application flexibility, simplicity and an increase in net returns to corn growers (Sikkema and Soltani 2007). In recent years, Dow AgroSciences has developed glyphosate/2,4-D-resistant corn hybrids. 2,4-D resistance is conferred by aryloxyalkanoate dioxygenase-1 (AAD-1) enzyme which results in increased 2,4-D and aryloxyphenoxypropionate metabolism (Anonymous 2012; Ruen et al. 2017; Skelton et al. 2017). It has been suggested that the introduction of these new technologies will significantly increase 2,4-D use in corn and other crops (Peterson et al. 2016). Currently, 
greater than $95 \%$ of corn produced in Canada is seeded to glyphosate/glufosinate-resistant hybrids, which in-part, has contributed to the selection of GR weeds and the need for a late postemergence application of 2,4-D.

Non-AAD-1 transformed corn hybrids have differential sensitivity to 2,4-D and can be injured with low application rates during the recommended application timing (Peterson et al. 2016). There have been few studies that have evaluated tolerance of non-AAD-1 transformed corn hybrids to 2,4-D in recent years. Additionally, tolerance of glyphosate/glufosinate-resistant corn to a tankmixture of 2,4-D and glyphosate has not been determined for Group 4 sensitive corn hybrids in Ontario. The adjuvant used in commercial glyphosate formulations may increase 2,4-D uptake and therefore affect the corn tolerance to this tankmixture.

The objective of this study was to determine the tolerance of two Group 4 sensitive glyphosate/glufosinate-resistant corn hybrids in Ontario (DeKalb DKC52-61 and Pioneer P0094AM) to 2,4-D (560 and $\left.1120 \mathrm{~g} \mathrm{ai} \mathrm{ha}^{-1}\right)$ and glyphosate (1800 $\mathrm{g}$ ae ha $\left.\mathrm{h}^{-1}\right)$ applied alone or in combination at V1, V3 or V5 application timings.

\section{Materials and Methods}

A study consisting of six field experiments (three with DeKalb DKC52-61 and three with Pioneer P0094AM corn hybrids) was conducted at the University of Guelph Ridgetown Campus, Ontario during 2015 and 2016 (two experiments were conducted in 2015 and four in 2016). The soil in 2015 was loam with $41 \%$ sand, 40\% silt, 19\% clay, $4.9 \%$ organic matter and pH of 6.2 . The soil at site 1 in 2016 was a silt with 53\% sand, 33\% silt, 14\% clay, 4.0\% organic matter and $\mathrm{pH}$ of 6.3 , and at site 2 was loam with $47 \%$ sand, $36 \%$ silt, $17 \%$ clay, $4.8 \%$ organic matter and $\mathrm{pH}$ of 6.2. Seedbed preparation at all sites consisted of fall moldboard plowing followed by two 
passes with a field cultivator with rolling basket harrows in the spring.

The study was established as a three-way factorial in a randomized complete block design with four replications. Factor one was application timing: corn at V1, V3 and V5; factor two was glyphosate (Roundup Weathermax ${ }^{\circledR}$ ) rate of 0 or $1800 \mathrm{~g}$ ae ha ${ }^{-1}$; and, factor three was 2,4-D amine rate of 0,560 or $1120 \mathrm{~g}$ ai ha ${ }^{-1}$. Plots consisted of two rows of corn that were spaced 0.75 $\mathrm{m}$ apart and $8.0 \mathrm{~m}$ long. Corn was planted at a population of approximately $80,000 \mathrm{seeds}^{-1}$ in early to late May of each year. Herbicide treatments were applied with a $\mathrm{CO}_{2}$-pressurized backpack sprayer equipped with Hypro ULD120-02 nozzle tips (Hypro, New Brighton, MN) calibrated to deliver $200 \mathrm{~L} \mathrm{ha}^{-1}$ of water at $200 \mathrm{kPa}$. Herbicide applications were made with a 1.0 $\mathrm{m}$ boom with three nozzles spaced $0.5 \mathrm{~m}$ apart producing a $1.5 \mathrm{~m}$ wide spray width. Herbicides were applied to corn at V1, V3 or V5. The entire experimental area was maintained weed-free by applying s-metolachlor/atrazine $\left(2880 \mathrm{~g} \mathrm{ai} \mathrm{ha}^{-1}\right)$ plus mesotrione $\left(140 \mathrm{~g}\right.$ ai ha $\left.{ }^{-1}\right)$ preemergence followed by glyphosate ( $900 \mathrm{~g}_{\text {ai ha }}{ }^{-1}$ ) at $\mathrm{V} 7$ and hand weeding as required.

Corn injury was visually estimated on a scale of 0 (no injury) to $100 \%$ (complete plant death) at 1 and 2 weeks after each application (WAT). Subsequent ratings were all made after the last application (WA-C) and included injury at 4 and 8 WA-C; average corn height (ten randomly selected plants in each plot), plant stand; percent goosenecking at 2 WA-C; percent brace root malformation at $8 \mathrm{WA}-\mathrm{C}$; and percent cob deformity just prior to harvest. The corn was harvested for grain with a small plot combine, weight and seed moisture content (maturity) were recorded, and grain yields were adjusted to $15.5 \%$ seed moisture content.

Data were analyzed as a 3-way factorial using PROC MIXED in SAS 9.4 (SAS 2015). The two corn hybrids (DeKalb DKC52-61 and Pioneer P0094AM) data were analyzed separately. Fixed effects included the three treatment factors: application timing, glyphosate rate and 2,4-D 
rate, as well as their interactions; random effects included year-location combinations (environment), interactions between environment and the fixed effects, and replicate nested within environment. Significance of fixed effects were tested using F-tests and random effects were tested using a Z-test of the variance estimate. The UNIVARIATE procedure was used to test data for normality and homogeneity of variance. To satisfy the assumptions of the variance analyses, percent injury 1 and 2 WAT, 4 and 8 WA-C, and percent goosenecking were square root transformed, and percent brace root malformation was arcsine square root transformed. An initial analysis was performed in PROC MIXED with hybrid and treatment as fixed effects to determine if corn hybrids could be combined for analysis; the hybrid by treatment interaction was significant for most variables and therefore corn hybrids were analyzed separately. The untreated control was excluded from analysis for the injury, goosenecking and brace root malformation ratings, but values were compared to zero independently (using lsmeans output). Comparisons were made using Tukey's test at a level of $\mathrm{P}=0.05$ and any data compared on the transformed scale were converted back to the original scale for presentation of results.

\section{Results and Discussion}

\section{DeKalb DKC52-61}

In general, injury increased as the application timing was delayed at 1 WAT, 2 WAT, 4 WA$\mathrm{C}$ and 8 WA-C (Table 1). There was no difference in plant stand, but plant height was reduced as the application timing was delayed from V1 to V3 (Table 1). There was an increase in goosenecking and brace-root malformation and a decrease in yield as the application timing was delayed (Table 1).

In general, visible injury at $8 \mathrm{WA}-\mathrm{C}$, goosenecking and brace root malformation increased as 
the application timing was delayed. This increase with delayed application, in injury, goosenecking and brace root malformation was present when 2,4-D was applied alone and in combination with glyphosate rate (averaged across three 2,4-D rates) (Table 2). There was no difference in corn injury between glyphosate rates ( $0 \mathrm{vs} 1800 \mathrm{~g}$ ae ha $\left.{ }^{-1}\right)$ at $\mathrm{V} 1$ but injury was increased by $7 \%$ at the V3 and V5 application timing. There was also no difference among the two glyphosate rates in goosenecking and brace root malformation at the V1 timing. However, the addition of glyphosate (1800 $\mathrm{g} \mathrm{ae} \mathrm{ha}^{-1}$ ) to 2,4-D increased goosenecking by 4 and $5 \%$ at V3 and V5, respectively and increased brace toot malformation 8 and 17\% at V3 and V5, respectively (Table 2).

As the application timing was delayed from V1 to V5, there was a trend to an increase in injury, goosenecking and brace root malformation at 560 and $1120 \mathrm{~g}$ ai ha ${ }^{-1}$ when visible injury, goosenecking and brace root malformation were compared as a function of 2,4-D rate and application timing (averaged across two glyphosate rates) (Table 3).

Visible injury and goosenecking generally increased as the rate of 2,4-D was increased and the injury was more severe when glyphosate $\left(1800 \mathrm{~g}\right.$ ae ha $\left.{ }^{-1}\right)$ was included in the tankmixture (Table 4). At 1 WAT, the co-application of 2,4-D with glyphosate (1800 $\mathrm{g}$ ae ha $\left.{ }^{-1}\right)$ increased injury $22 \%$ at $560 \mathrm{~g}$ ai ha ${ }^{-1}$ and $35 \%$ at $1120 \mathrm{~g}$ ai ha $\mathrm{ha}^{-1}$ (Table 4). Corn height and yield were not affected by 2,4-D when glyphosate was not included in the mixture but decreased when 2,4-D was co-applied with glyphosate (1800 $\mathrm{g} \mathrm{ae} \mathrm{ha}^{-1}$ ) (Table 4). Grain corn yield decreased 8\% with 2,4-D applied at $560 \mathrm{~g}_{\text {ai ha }}{ }^{-1}$ and $12 \%$ at $1120 \mathrm{~g}$ ai ha $^{-1}$ (Table 1).

Corn injury with 2,4-D observed in this study is similar to other studies with 2,4-D that have shown significant injury can occur when 2,4-D rate is increased, especially when application timing is delayed beyond $15 \mathrm{~cm}$ tall corn (Rossman and Sprague 1949; Rossman and Staniforth 
1949; Rateliff and Cowart 1951; Rodgers 1952; Guzman and Wolf 1953). Guzman and Wolf (1953) found no injury in corn with 2,4-D amine applied postemergence at $840 \mathrm{~g}^{\mathrm{ai} \mathrm{ha}} \mathrm{ha}^{-1}$ to various hybrids of corn when they were less than $7.5 \mathrm{~cm}$ tall. Other researchers have found corn injury and lower yield with 2,4-D applied at $1120 \mathrm{~g}$ ai ha ${ }^{-1}$ in some corn hybrids (Rodgers 1952).

\section{Pioneer P0094AM}

In general, as the application timing was delayed, there was a trend to increased injury at 1 WAT, 2 WAT, 4 WA-C and 8 WA-C in Pioneer P0094AM corn (Table 5). There was no effect of herbicide application timing on corn height, plant stand, or yield but goosenecking and braceroot malformation increased as the application timing was delayed (Table 5).

Visible injury, goosenecking and brace root malformation generally increased as the application timing was delayed when visible injury, goosenecking and brace root malformation in Pioneer P0094AM field corn was compared as a function of either rate of glyphosate and application timing, averaged across three 2,4-D rates (Table 6). Generally no difference between glyphosate rates (1800 vs $0 \mathrm{~g}_{\text {ae ha }}{ }^{-1}$ ) at V1 but at V3 and V5, visible injury, goosenecking and brace root malformation was as much as $19 \%$ greater with glyphosate $\left(1800 \mathrm{~g} \mathrm{ae} \mathrm{ha}^{-1}\right)$ in the tankmixture (Table 6).

As the application timing was delayed from V1 to V5, there was a trend to increased injury, goosenecking and brace root malformation at 560 and $1120 \mathrm{~g}_{\text {ai ha }}{ }^{-1}$ when comparing injury, goosenecking and brace root malformation as a response to 2,4-D rate and application timing (averaged across two glyphosate rates) (Table 7). Additionally, when injury and corn yield were compared as a response to glyphosate rate and 2,4-D rate (averaged across three application timings), there was as much as $13 \%$ increase in visible injury at $560 \mathrm{~g}$ ai ha ${ }^{-1}$ and $24 \%$ increase in 
visible injury at $1120 \mathrm{~g}$ ai ha $^{-1}$ with $2,4-\mathrm{D}$ when co-applied with glyphosate $\left(1800 \mathrm{~g}\right.$ ae ha $\left.\mathrm{ha}^{-1}\right)$ (Table 8). Yield was also reduced 6\% with 2,4-D at $1120 \mathrm{~g}$ ai ha ${ }^{-1}$ when glyphosate $(1800 \mathrm{~g}$ ae $\mathrm{ha}^{-1}$ ) was in the tankmixture (Table 8).

This study concludes that both DeKalb DKC52-61 and Pioneer P0094AM corn hybrids are sensitive to 2,4-D amine applied at V1, V3 and V5. The addition of glyphosate (1800 $\mathrm{g}$ ae ha $\left.{ }^{-1}\right)$ to $2,4-\mathrm{D}$ amine at 560 and $1120 \mathrm{~g}$ ai ha $^{-1}$ resulted in increased visible injury, goosenecking, brace root malformation and yield reduction in DeKalb DKC52-61 and Pioneer P0094AM corn hybrids under Ontario environmental conditions. Injury was generally greater as the 2,4-D application rate increased and application timing was delayed. The authors speculate that the increased corn injury observed in this study when glyphosate is added to 2,4-D may be attributed to the adjuvants present in the formulated glyphosate product which increases uptake of 2,4-D and causes accentuated corn injury.

\section{Acknowledgements}

Funding for this study was made possible through Grain Farmers of Ontario and the Growing Forward 2 program of the Agricultural Adaptation Council.

\section{References}

Anonymous. 2012. Technical Bulletin: A System approach to Broad-Spectrum weed management for corn, soybeans and cotton. Dow AgroSciences publication Indianapolis, Indiana, USA.

Budd, C.M., Soltani, N., Robinson, D.E., Hooker, D.C., Miller, R.T., and Sikkema, P.H. 2017. Distribution of glyphosate and cloransulam-methyl resistant Canada fleabane [Conyza 
canadensis (L.) Cronq.] in Ontario. Can. J. of Plant Sci. XX:XXX-XXX.

Byker, H.P., Soltani, N., Robinson, D., Tardif, F., Lawton, M., and Sikkema P.H. 2013. Control of glyphosate-resistant Canada fleabane (Conyza canadensis (L.) Cronq.) with preplant herbicide tankmixes in soybean (Glycine max. (L). Merr.). Can J. Plant Sci. 93:659-667.

Ellis, N.K., and Bullard, E.T. 1948. Varietal response of sweet corn to 2,40D spray, and the effect of different formulations of 2,4]D on yield. Amer. Soc. Hort. Sci. Proc. 51:505]508.

Follings, J., Soltani, N., Robinson, D.E., Tardif, F.J., Lawton, M.B., and Sikkema, P.H. 2013. Distribution of glyphosate and cloransulam -resistant giant ragweed (Ambroisa trifida L.) populations in southern Ontario. Agricultural Sci. 4(10): 570-576. 
Guzman, V.L., and Wolf, E.A. 1953. Effect of 2,4-D on Four Sweet Corn Hybrids at Different Stages of Growth. Proc. of Florida State Hort. Soc. 66:141-147.

Keeling, W.J., Henniger, G.C., and Abernathy, J.R. 1989. Horseweed (Conyza canadensis) control in conservation tillage cotton (Gossypium hirsutum). Weed Technol. 3:399-401.

Kruger, G.R., Davis, V.M., Weller S.C., and Johnson, W.G. (2010) Control of Horseweed (Conyza canadensis) with growth regulator herbicides. Weed Technol. 24:425-429.

Munro, I.C., Carlo, G.L., Orr, J.C., Sund, K.G., Wilson, R.M., Kennepohl, E., Lynch, B.S.,

8
Jablinske, M., and Lee, N.L. 1992. A Comprehensive, Integrated Review and Evaluation of the Scientific Evidence Relating to the Safety of the Herbicide 2,4-D. J. Am. Coll. Toxicol. 11:559-664.

[OMAFRA] Ontario Ministry of Agriculture, Food and Rural Affairs. 2017. Guide to weed control. Publication 75. Toronto, ON. Canada. 458 pp.

Peterson, M., McMaster, S., Riechers, D., Skelton, J., and Stahlman, P. 2016. 2,4-D Past, Present, and Future: A Review. Weed Technol.: 30(2):303-345.

Rodgers, E.G. 1952. Brittleness and Other Responses of Corn to 2,4-Dichlorophenoxyacetic Acid. Plant Physiol. 27:153-172.

Rossman, E.C., and G. F. Sprague. 1949. Effect of 2,40? on yield of maize in the succeeding generation after treatment. Plant Physiol. 24:770?773.

Rossman, E.C., and Staniforth, D.W. 1949. Effects of 2,4-D on inbred lines and a single cross of maize. Plant Physiol 24:60-74.

Ruen, D.C., Scherder, E.F., Ditmarsen, S.C., Prasifka, P.L., Ellis, J.M., Simpson, D.M., Gallup, C.A., and Hopkins, B.W. 2017. Tolerance of Corn with Glyphosate Resistance and the Aryloxyalkanoate Dioxygenase Trait (AAD-1) to 2, 4-D Choline and Glyphosate. Weed 
Technology, 31(2): 217-224.

Schryver, M., Soltani, N., Hooker, D.C., Robinson, D.E., Tranel, P.J., and Sikkema, P.H. 2017. Glyphosate resistant waterhemp (Amaranthus tuberculatus var. rudis) in Ontario, Canada. Can. J. of Plant Sci. XX:XXX-XXX.

Shaner, D.L. 2014. Herbicide Handbook, Tenth Edition. Champaign, IL: Weed Sci. Soc. Am., 513 pp.

Sikkema, P.H., and Soltani, N. 2007. Herbicide-Resistant Crops in Eastern Canada. In: Gulden, R.H. and Swanton, C.J., Eds., The First Decade of Herbicide-Resistant Crops in Canada. Topics in Canadian Weed Science, Sainte Anne de Bellevue, Quebec, 3-13.

Skelton, J.J., Simpson, D.M., Peterson, M.A., and Riechers, D.E. 2017. Comparative Analysis of 2, 4-D Uptake, Translocation, and Metabolism in Non-AAD-1 Transformed and 2, 4-DResistant Corn. Weed Sci. pp.1-12.

Statistical Analysis Systems (SAS). 2015. The SAS System for Windows, Release 9.4. Cary, NC: Statistical Analysis Systems Institute.

Van Wely, A.C., Soltani, N., Robinson, D.E., Hooker, D.C., Lawton, M.B., and Sikkema, P.H. 2015. Glyphosate and acetolactate synthase resistant common ragweed (Ambrosia artemisiifolia L.) in southwestern Ontario. Can. J. of Plant Sci. 95:335-338. 
Table 1. Significance of main effects and interaction for percent visible injury, height, plant stand, percent goosenecking, percent brace root malformation and yield for DeKalb DKC52-61 field corn treated with glyphosate and/or 2,4-D at various timings at Ridgetown, ON from 2015 to $2016^{\mathrm{a}, \mathrm{b}}$

\begin{tabular}{|c|c|c|c|c|c|c|c|c|c|}
\hline \multirow[b]{2}{*}{ Main effects } & \multicolumn{4}{|c|}{ Injury } & \multirow[b]{2}{*}{ Height } & \multirow{3}{*}{$\frac{\text { Stand }}{\text { Plants }}{ }^{\mathrm{m}-1}$} & \multicolumn{3}{|c|}{ Brace root } \\
\hline & $1 \mathrm{WAT}$ & $2 \mathrm{WAT}$ & $4 \mathrm{WA}-\mathrm{C}$ & $8 \mathrm{WA}-\mathrm{C}$ & & & Goosenecking & malformation & Yield \\
\hline & \multicolumn{4}{|c|}{$\%$} & $\mathrm{~cm}$ & & \multicolumn{2}{|c|}{$\%$} & $\mathrm{~T} \mathrm{ha}^{-1}$ \\
\hline Application timing & $*$ & $* *$ & $* *$ & $* *$ & $*$ & NS & $* *$ & $* *$ & $*$ \\
\hline V1 & 3 & 2 & 0 & 0 & $122 \mathrm{a}$ & 6.7 & 0 & 0 & $15.4 \mathrm{a}$ \\
\hline V3 & 14 & 9 & 5 & 4 & $118 \mathrm{~b}$ & 6.6 & 3 & 6 & $14.1 \mathrm{~b}$ \\
\hline V5 & 12 & 10 & 9 & 14 & $120 \mathrm{ab}$ & 6.7 & 5 & 37 & $14.3 \mathrm{~b}$ \\
\hline Glyphosate rate (g ae/ha) & $*$ & $*$ & $*$ & $* *$ & $* *$ & NS & $* *$ & $* *$ & $*$ \\
\hline 0 & 4 & 2 & 2 & 3 & 121 & 6.8 & 0 & 6 & 14.8 \\
\hline 1800 & 17 & 12 & 7 & 6 & 118 & 6.5 & 3 & 12 & 14.3 \\
\hline $2,4-D$ rate $(g$ ai $/ h a)$ & $* *$ & $* *$ & $* *$ & $* *$ & $* *$ & NS & $* *$ & $* *$ & $*$ \\
\hline 0 & 0 & 0 & 0 & 0 & 124 & 6.8 & 0 & 0 & 15.6 \\
\hline 560 & 13 & 9 & 5 & 6 & 119 & 6.6 & 2 & 14 & 14.3 \\
\hline 1120 & 24 & 16 & 11 & 11 & 117 & 6.6 & 5 & 24 & 13.8 \\
\hline \multicolumn{10}{|l|}{ Interactions } \\
\hline $\mathrm{T} \times \mathrm{G}$ & NS & NS & NS & $*$ & NS & NS & $* *$ & $* *$ & NS \\
\hline $\mathrm{T} \times \mathrm{D}$ & $* *$ & $* *$ & $* *$ & $* *$ & NS & NS & $* *$ & $* *$ & NS \\
\hline G x D & $*$ & $* *$ & $*$ & NS & $*$ & NS & $*$ & NS & $* *$ \\
\hline$T \times G \times D$ & NS & NS & NS & NS & NS & NS & NS & NS & NS \\
\hline
\end{tabular}

${ }^{a}$ Abbreviations: D, 2,4-D rate; G, glyphosate rate; NS, not significant at $\mathrm{P}=0.05$ level; T, application timing; V1, 1 corn leaf collar visible; V3, 3 corn leaf collars visible; V5, 5 corn leaf collars visible; WAT, weeks after each postemergence herbicide application; WA-C, weeks after last postemergence herbicide application.

${ }^{b}$ Means followed by a different letter within a column are significantly different according to Tukey's test at P $<0.05$. Means for a main effect were separated only if there was no significant interaction involving that main effect. Significance at $\mathrm{P}<0.05$ and $\mathrm{P}<0.01$ levels denoted by $*$ and $* *$, respectively. 
Table 2. Percent visible injury, goosenecking and brace root malformation in DeKalb DKC52-61 field corn as a function of glyphosate rate and application timing, averaged across three 2,4-D rates, at Ridgetown, ON from 2015 to $2016{ }^{\mathrm{a}, \mathrm{b}}$

\begin{tabular}{|c|c|c|c|}
\hline \multirow[b]{2}{*}{ Application timing by variable } & \multicolumn{2}{|c|}{ Glyphosate rate $\left(\mathrm{g} \mathrm{ae} \mathrm{ha}^{-1}\right)$} & \\
\hline & 0 & 1800 & \\
\hline \multirow{2}{*}{\multicolumn{4}{|c|}{ Injury $8 W A-C$}} \\
\hline & & & \\
\hline V3 & & & \\
\hline V5 & & & \\
\hline \multirow{2}{*}{\multicolumn{4}{|c|}{ Goosenecking }} \\
\hline & & & \\
\hline V1 & 0 a Z & 0 a $Z$ & \\
\hline V3 & $1 \mathrm{ab} \mathrm{Z}$ & $5 \mathrm{~b} \mathrm{Y}$ & \\
\hline V5 & $2 \mathrm{~b} Z$ & $7 \mathrm{~b} \mathrm{Y}$ & \\
\hline \multicolumn{4}{|l|}{ Brace root malformation } \\
\hline V1 & 0 a $Z$ & 0 a Z & \\
\hline V3 & 3 a Z & $11 \mathrm{~b} \mathrm{Y}$ & \\
\hline V5 & $28 \mathrm{~b} \mathrm{Z}$ & 45 c Y & \\
\hline \multicolumn{4}{|c|}{$\begin{array}{l}\text { Abbreviations: NS, not significant at } \mathrm{P}=0.05 \text { level; } \mathrm{V} 1,1 \text { corn leaf collar visible; } \mathrm{V} 3,3 \text { corn leaf collars visible; V5, } 5 \text { corn } \\
\text { leaf collars visible; WAT, weeks after each postemergence herbicide application; WA-C, weeks after last postemergence } \\
\text { herbicide application. } \\
\text { b Means followed by a different letter within a column (a-c) for each variable or row (Y-Z) are significantly } \\
\text { different according to Tukey's test at } \mathrm{P}<0.05 \text {. }^{\text {a }}\end{array}$} \\
\hline
\end{tabular}


Table 3. Percent visible injury, goosenecking and brace root malformation in DeKalb DKC52-61 field corn as a function of 2,4-D rate and application timing, averaged across two glyphosate rates, at Ridgetown, ON from 2015 to 2016 .

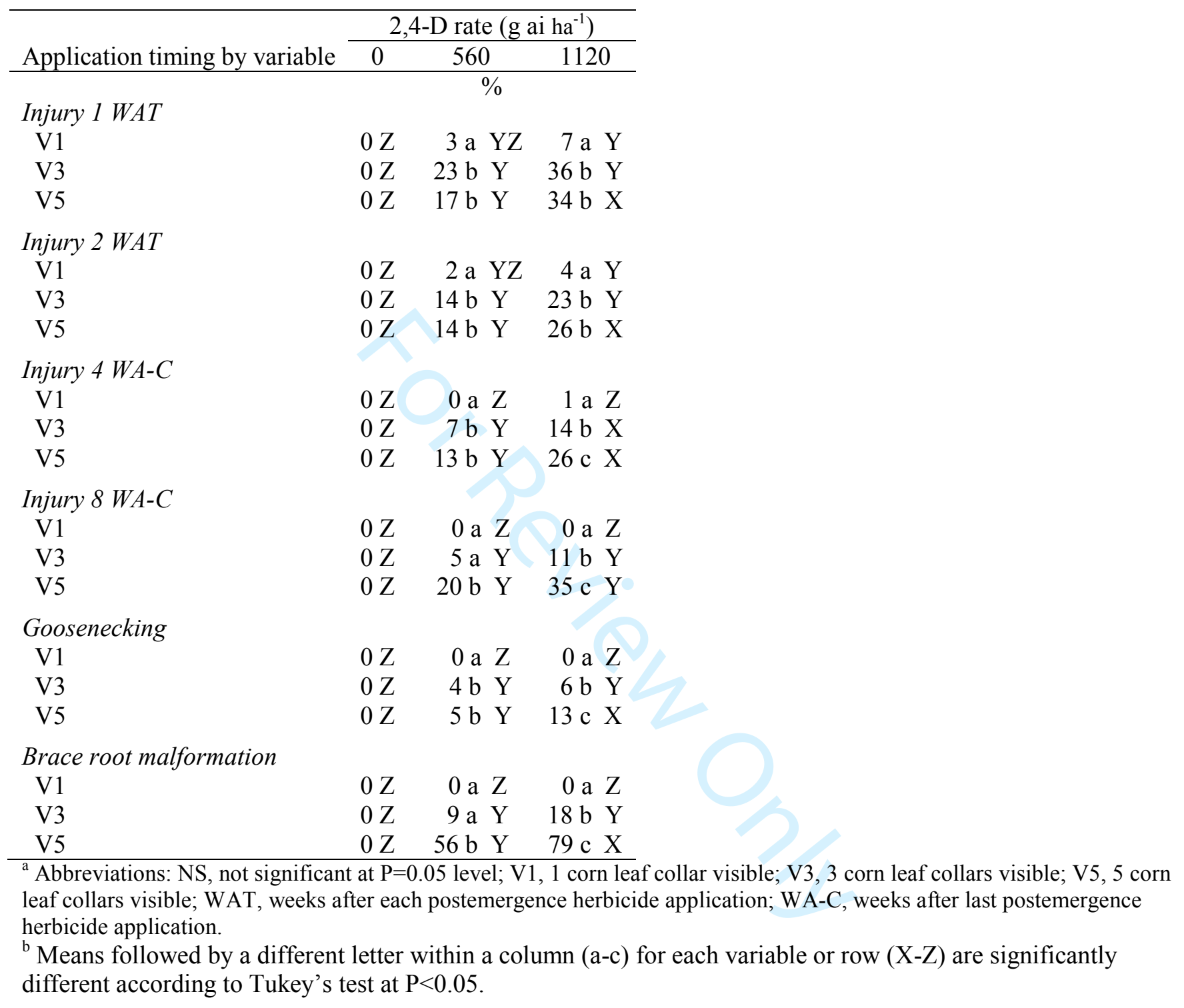


Table 4. Percent visible injury, goosenecking and yield in DeKalb DKC52-61 field corn as a function of glyphosate rate and 2,4-D rate, averaged across three application timings, at Ridgetown, ON from 2015 to 2016 . ${ }^{\text {a,b }}$

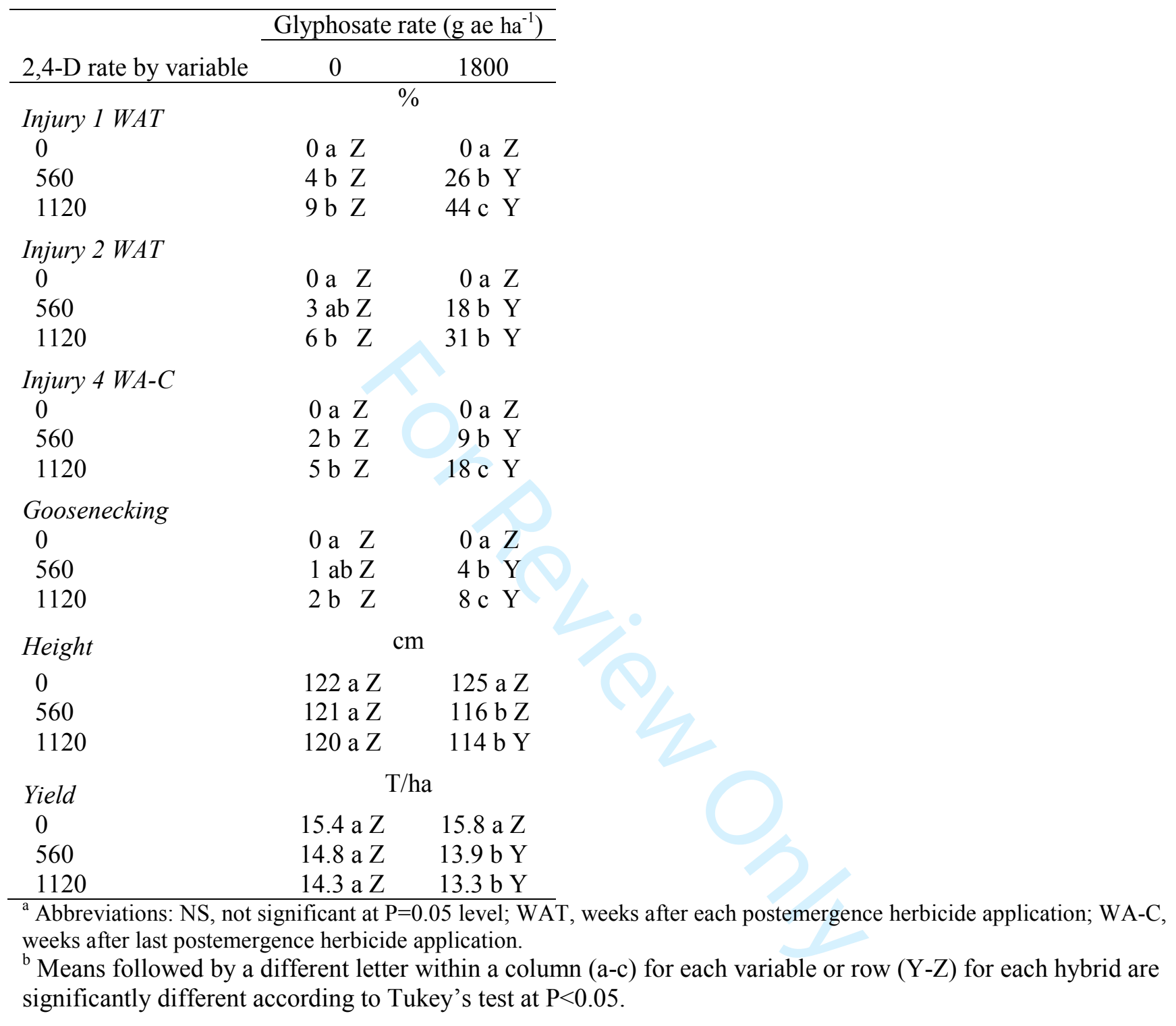


Table 5. Significance of main effects and interaction for percent visible injury, height, plant stand, percent goosenecking, percent brace root malformation and yield for Pioneer P0094AM field corn treated with glyphosate and/or 2,4-D at various timings at Ridgetown, ON from 2015 to 2016. ${ }^{\mathrm{a}, \mathrm{b}}$

\begin{tabular}{|c|c|c|c|c|c|c|c|c|c|}
\hline \multirow[b]{2}{*}{ Main effects ${ }^{b}$} & \multicolumn{4}{|c|}{ Injury } & \multirow[b]{2}{*}{ Height } & \multirow[b]{2}{*}{ Stand } & \multirow[b]{2}{*}{ Goosenecking } & \multicolumn{2}{|l|}{ Brace root } \\
\hline & $1 \mathrm{WAT}$ & $2 \mathrm{WAT}$ & $4 \mathrm{WA}-\mathrm{C}$ & $8 \mathrm{WA}-\mathrm{C}$ & & & & malformation & Yield \\
\hline & \multicolumn{4}{|c|}{$\%$} & $\mathrm{~cm}$ & Plants $\mathrm{m}^{-1}$ & \multicolumn{2}{|c|}{$\%$} & $\mathrm{t} \mathrm{ha}^{-1}$ \\
\hline Application timing & $*$ & $*$ & $* *$ & $* *$ & NS & NS & $*$ & $* *$ & NS \\
\hline V1 & 1 & 1 & 0 & 0 & 125 & 6.8 & 0 & 0 & 14.8 \\
\hline V3 & 8 & 4 & 3 & 2 & 123 & 6.7 & 1 & 4 & 14.6 \\
\hline V5 & 11 & 7 & 7 & 11 & 124 & 6.7 & 2 & 32 & 14.1 \\
\hline Glyphosate rate (g ae/ha) & $* *$ & $*$ & $* *$ & $* *$ & NS & NS & $*$ & $* *$ & NS \\
\hline 0 & 2 & 1 & 1 & 2 & 125 & 6.8 & 0 & 4 & 14.6 \\
\hline 1800 & 11 & 7 & 4 & 4 & 124 & 6.7 & 2 & 11 & 14.4 \\
\hline $2,4-D$ rate $(g$ ai $/ h a)$ & $* *$ & $* *$ & $* *$ & $* *$ & NS & $*$ & $* *$ & $* *$ & $* *$ \\
\hline 0 & 0 & 0 & 0 & 0 & 127 & $6.9 \mathrm{a}$ & 0 & 0 & 15.1 \\
\hline 560 & 8 & 4 & 3 & 4 & 124 & $6.6 \mathrm{~b}$ & 1 & 11 & 14.4 \\
\hline 1120 & 16 & 9 & 7 & 7 & 122 & $6.8 \mathrm{a}$ & 2 & 20 & 14.0 \\
\hline \multicolumn{10}{|l|}{ Interactions } \\
\hline $\mathrm{T} \times \mathrm{G}$ & $* *$ & $* *$ & $* *$ & $* *$ & NS & NS & $* *$ & $* *$ & NS \\
\hline $\mathrm{T} \times \mathrm{D}$ & $* *$ & $* *$ & $* *$ & $* *$ & NS & NS & $* *$ & $* *$ & NS \\
\hline Gx D & $*$ & NS & $*$ & NS & NS & NS & NS & NS & $*$ \\
\hline $\mathrm{T} \times \mathrm{G} \times \mathrm{D}$ & NS & NS & NS & NS & NS & NS & NS & NS & NS \\
\hline
\end{tabular}

T x G x D

visible; V5, 5 corn leaf collars visible; WAT, weeks after each postemergence herbicide application; WA-C, weeks after last postemergence herbicide application.

${ }^{\mathrm{b}}$ Means followed by a different letter within a column are significantly different according to Tukey's test at P $<0.05$. Means for a main effect were separated only if there was no significant interaction involving that main effect. Significance at $\mathrm{P}<0.05$ and $\mathrm{P}<0.01$ levels denoted by $*$ and $* *$, respectively. 
Table 6. Percent visible injury, goosenecking and brace root malformation in Pioneer P0094AM field corn as a function of glyphosate rate and application timing, averaged across three 2,4-D rates, at Ridgetown, ON from 2015 to $2016 .^{\mathrm{a}, \mathrm{b}}$

\begin{tabular}{|c|c|c|}
\hline \multirow[b]{2}{*}{$\begin{array}{l}\text { Application timing by } \\
\text { variable }\end{array}$} & \multicolumn{2}{|c|}{ Glyphosate rate $\left(\mathrm{g} \mathrm{ae} \mathrm{ha}^{-1}\right)$} \\
\hline & 0 & 1800 \\
\hline Injury 1 WAT & \multicolumn{2}{|c|}{$\%$} \\
\hline V1 & 0 a $Z$ & 3 a $Y$ \\
\hline V3 & 2 a $Z$ & $17 \mathrm{~b} \mathrm{Y}$ \\
\hline V5 & 6 a $Z$ & $18 \mathrm{~b} \mathrm{Y}$ \\
\hline \multicolumn{3}{|l|}{ Injury $2 W A T$} \\
\hline V1 & 0 a $Z$ & 1 a $Z$ \\
\hline V3 & 1 a $Z$ & $9 \mathrm{~b} \mathrm{Y}$ \\
\hline V5 & 4 a $Z$ & $12 \mathrm{~b} \mathrm{Y}$ \\
\hline \multicolumn{3}{|l|}{ Injury $4 W A-C$} \\
\hline $\mathrm{V} 1$ & 0 a $\mathrm{Z}$ & 0 a Z \\
\hline V3 & $1 \mathrm{ab} Z$ & $5 \mathrm{~b} \mathrm{Y}$ \\
\hline V5 & $3 \mathrm{~b} Z$ & $11 \mathrm{c} \mathrm{Y}$ \\
\hline \multicolumn{3}{|l|}{ Injury $8 W A-C$} \\
\hline V1 & 0 a $Z$ & $0 \mathrm{a} \quad \mathrm{Z}$ \\
\hline $\mathrm{V} 3$ & $1 \mathrm{ab} Z$ & $4 a b Y$ \\
\hline V5 & $8 \mathrm{~b} \quad \mathrm{Z}$ & $14 \mathrm{~b} Y$ \\
\hline \multicolumn{3}{|l|}{ Goosenecking } \\
\hline V1 & 0 a Z & 0 a $Z$ \\
\hline V3 & 0 a Z & $1 \mathrm{ab} Z$ \\
\hline V5 & $1 \mathrm{a} \mathrm{Z}$ & $4 \mathrm{~b} Y$ \\
\hline \multicolumn{3}{|l|}{ Brace root malformation } \\
\hline $\mathrm{V} 1$ & 0 a Z & 0 a $Z$ \\
\hline V3 & 1 a Z & $7 \mathrm{~b} \mathrm{Y}$ \\
\hline V5 & $23 \mathrm{~b} \mathrm{Z}$ & $42 \mathrm{c} \mathrm{Y}$ \\
\hline
\end{tabular}

${ }^{a}$ Abbreviations: NS, not significant at $\mathrm{P}=0.05$ level; V1, 1 corn leaf collar visible; V3, 3 corn leaf collars visible; V5, 5 corn leaf collars visible; WAT, weeks after each postemergence herbicide application; WA-C, weeks after last postemergence herbicide application.

${ }^{\mathrm{b}}$ Means followed by a different letter within a column (a-c) for each variable or row (Y-Z) are significantly different according to Tukey's test at $\mathrm{P}<0.05$. 
1 Table 7. Percent visible injury, goosenecking and brace root malformation in Pioneer P0094AM field corn as a function of 2,4-D rate and application timing, averaged across two glyphosate rates, at Ridgetown, ON from 2015 to 2016 . $^{\text {a,b }}$

\begin{tabular}{|c|c|c|c|c|}
\hline \multirow[b]{2}{*}{ Application timing by variable } & \multicolumn{3}{|c|}{ 2,4-D rate $\left(\mathrm{g}\right.$ ai ha $\left.{ }^{-1}\right)$} & \\
\hline & 0 & 560 & 1120 & \\
\hline \multicolumn{4}{|l|}{ Injury 1 WAT } & \\
\hline V1 & $0 \mathrm{Z}$ & 1 a Z & 3 a Z & \\
\hline V3 & $0 \mathrm{Z}$ & $11 \mathrm{ab} \mathrm{Y}$ & $21 \mathrm{~b} \mathrm{Y}$ & \\
\hline V5 & $0 \mathrm{Z}$ & $15 \mathrm{~b} \quad \mathrm{Y}$ & $31 \mathrm{~b} \mathrm{Y}$ & \\
\hline \multicolumn{5}{|l|}{ Injury $2 W A T$} \\
\hline V1 & $0 \mathrm{Z}$ & $0 \mathrm{a} Z$ & 2 a $Z$ & \\
\hline $\mathrm{V} 3$ & $0 \mathrm{Z}$ & $5 \mathrm{ab} Y$ & $11 \mathrm{~b} \mathrm{Y}$ & \\
\hline V5 & $0 \mathrm{Z}$ & $9 \mathrm{~b} Y$ & $21 \mathrm{~b} \mathrm{Y}$ & \\
\hline \multicolumn{5}{|l|}{ Injury $4 W A-C$} \\
\hline $\mathrm{V} 1$ & $0 \mathrm{Z}$ & 0 a Z & 0 a Z & \\
\hline V3 & $0 \mathrm{Z}$ & $3 a b Y$ & $7 \mathrm{~b} \mathrm{X}$ & \\
\hline V5 & $0 \mathrm{Z}$ & $8 \mathrm{~b} \quad \mathrm{Y}$ & $19 \mathrm{c} \mathrm{X}$ & \\
\hline \multicolumn{5}{|l|}{ Injury $8 W A-C$} \\
\hline V1 & $0 \mathrm{Z}$ & 0 a Z & 0 a $Z$ & \\
\hline V3 & $0 \mathrm{Z}$ & 2 a YZ & 5 a Y & \\
\hline V5 & $0 \mathrm{Z}$ & $16 \mathrm{~b} \mathrm{Y}$ & $28 \mathrm{~b} \mathrm{Y}$ & \\
\hline \multicolumn{5}{|l|}{ Goosenecking } \\
\hline V1 & $0 \mathrm{Z}$ & 0 a $Z$ & 0 a Z & \\
\hline V3 & $0 \bar{Z}$ & $1 \mathrm{a} \mathrm{Z}$ & $2 \mathrm{a} \mathrm{Z}$ & \\
\hline V5 & $0 \mathrm{Z}$ & $2 \mathrm{a} \mathrm{Z}$ & $6 \mathrm{~b} \mathrm{Y}$ & \\
\hline \multicolumn{5}{|l|}{ Brace root malformation } \\
\hline $\mathrm{V} 1$ & $0 \mathrm{Z}$ & 0 a Z & 0 a Z & \\
\hline V3 & $0 \mathrm{Z}$ & 4 a Y & $12 \mathrm{~b} \mathrm{Y}$ & \\
\hline V5 & $0 \mathrm{Z}$ & $50 \mathrm{~b} \mathrm{Y}$ & 72 c X & \\
\hline \multicolumn{5}{|c|}{$\begin{array}{l}{ }^{\mathrm{a}} \text { Abbreviations: NS, not significant at } \mathrm{P}=0.05 \text { level; } \mathrm{V} 1,1 \text { corn leaf collar visible; } \mathrm{V} 3,3 \text { corn leaf collars visible; } \\
\text { V5, } 5 \text { corn leaf collars visible; WAT, weeks after each postemergence herbicide application; WA-C, weeks after last } \\
\text { postemergence herbicide application. } \\
{ }^{b} \text { Means followed by a different letter within a column (a-c) for each variable or row }(\mathrm{X}-\mathrm{Z}) \text { are }\end{array}$} \\
\hline
\end{tabular}


10 Table 8. Percent visible injury and yield in Pioneer P0094AM field corn as a function of glyphosate rate and 2,4-D rate, averaged across three application timings, at Ridgetown, ON from 2015 to 2016.

12

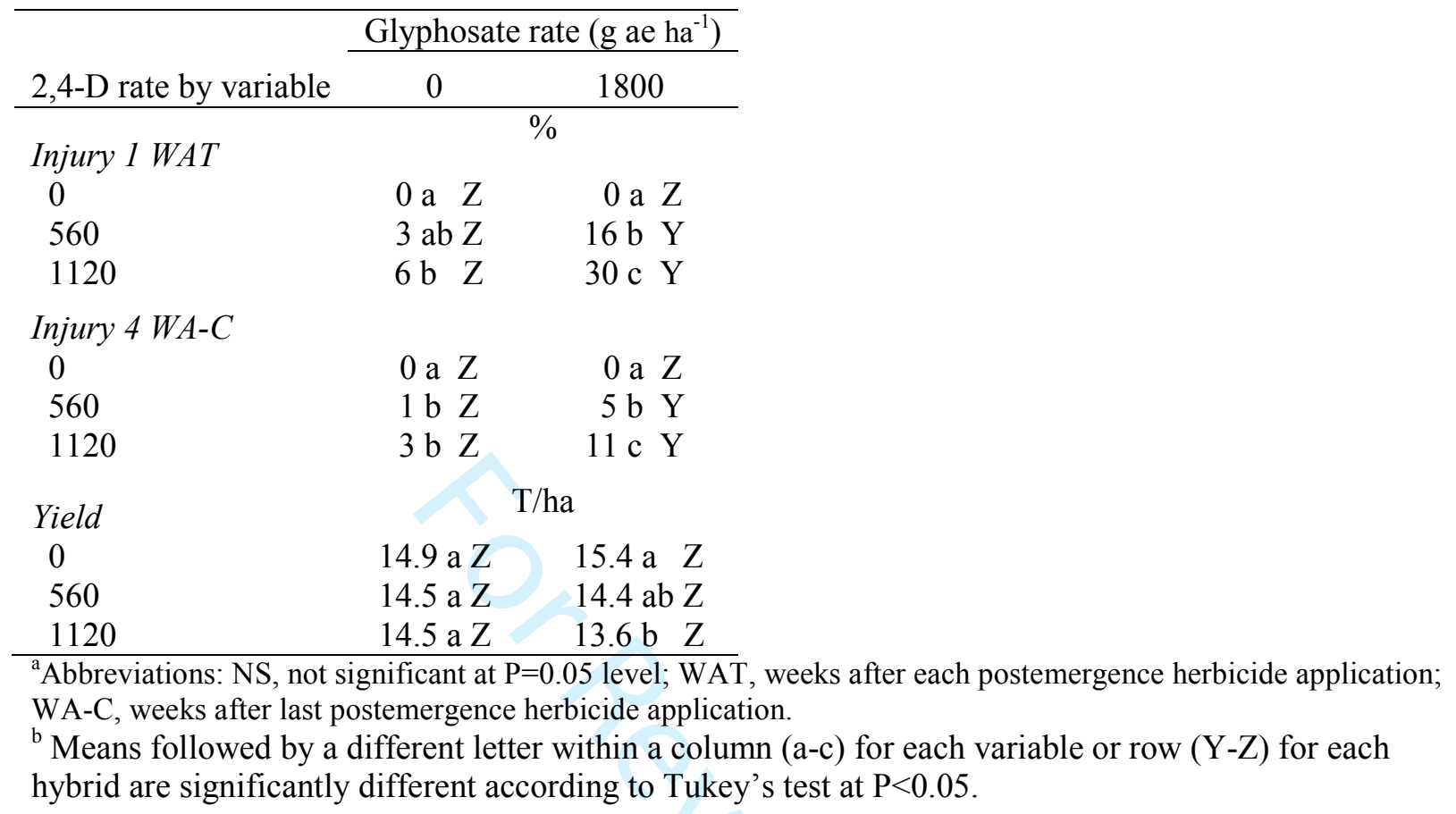

